\title{
Superhero, Sleeping Beauty, or Devil? The Making of Orphan Myths and Public Administration
}

\author{
Mariglynn Edlins, Ph.D. \\ Assistant Professor, School of Health and Human Services \\ University of Baltimore, medlins@ubalt.edu
}

Mariglynn Edlins, Ph.D., is an Assistant Professor of Human Services Administration at the University of Baltimore. Her research is focused on translations of democracy within our everyday interactions with government. Specifically, she is interested in the ways that citizensboth adults and children - interact and engage with their government through individuals, institutions, technology, and policy. 


\begin{abstract}
Children who are separated from their parents, whether temporarily or permanently, become dependent on representatives of the state to make the day-to-day decisions of their care. In these interactions with vulnerable children, these representatives rely on their own discretion to guide them in how to approach the children they are responsible for. What stories exist that might influence how street-level bureaucrats think about children who are separated from their parents? What narratives might inform the discretion and judgment they use in their work? In this paper, I explore the narratives of superhero stories, romance novels, and horror films in order to identify the orphan archetypes they portray and consider how these myths might impact the interactions between orphans and public administrators.
\end{abstract}




\section{Introduction}

In the 2009 movie, Case 39, Emily Jenkins is a social worker who develops a protective relationship with a young girl. When she confirms that Lilith's parents have tried to kill her, Lilith is removed from her parents and placed in foster care. The young girl convinces Emily to take her in and then mysterious things start happening. Lilith transforms from a sweet child to a demonic, possessed creature. As the film progresses, the interactions between Emily, the public servant, and Lilith, the demon, veer into the absurd and end in a dramatic murder.

With a professional background working with children in the foster care system, I was surprised to see a child in such a vulnerable position portrayed this way. While I recognize the intention for entertainment, a narrative such as this one about children who are separated from their parents is concerning. What does it communicate to us generally about who these children are and what they are going through? And perhaps even more important, what does it communicate or support in the thinking and judgment of individuals who work with children on the front lines of public service? With these questions in mind, I set out to explore popular narratives that might influence general thinking about these children, as well as the governance they receive through public administration.

In this paper I trace three popular narrative genres — superheroes stories, romantic fairytales, and horror films - that tell multiple stories about children who are temporarily or permanently separated from their parents, often called orphans. I am interested first in what myths about orphans emerge from these narratives, including archetypes about who they are, how they think and feel, as well how they should be treated. Additionally, I am interested in how these myths might influence the interactions between children who are separated from their parents and the public servants who represent the state. The paper will proceed as follows: the 
first section reviews the relationship between orphan children and public administration, exploring the foundational concepts for this relationship, as well as the relevance of popular genres. In subsequent sections, I trace the archetypes of orphans that emerge from each of the three narrative genres, identify how these myths might play out in interactions between children who are separated from their parents and public administrators, and consider the broader possible implications of these myths.

\section{Orphans and Public Administration}

Though citizens in the formal sense, children are functionally deprived of the capacity to participate in the decisions that affect them most. "Judged to be incapable of citizenship in that they cannot make the rational and informed decisions that characterize self-governance" (Cohen $2005,221)$, children are dependent on adults to act for them and to make decisions in their best interest. Within families, governance is generally provided for children by one or two parents. However, for children temporarily or permanently without parents to govern them, this creates a considerable dilemma. Many of these children may not be orphans in the traditional sense but nonetheless "have one, sometimes two, parents, who can't or won't care for them" (Toth 1998, 20) for a period of time. Whether through "the death or disappearance of, abandonment or desertion by, or separation or loss from, both parents" (U.S. Citizenship and Immigration Services 2011), these children are indeed orphans. In this paper, I use the term "orphan" to represent a child who separated from their parents, whether temporarily such as the case of foster care, juvenile detention, or mandated in-patient drug rehabilitation, as well as a more permanent situation such as jail or waiting for adoption. 
As an extension of the parens patriae doctrine (Latin for "parent of the nation"), the state has the power to step in when there is an absence of appropriate parental care. For these children who are separated from their parents whether permanently or temporarily, the individuals who represent the state become very important. While all children come into direct contact with public servants through state and local agencies, orphans become dependent on them to care for them and act on their behalf. When the state steps in as "parent" of orphan children, the day-today decisions in this child's life are made by representatives of the state, often referred to as street-level bureaucrats. These frontline bureaucrats work directly with orphan children: they are social workers, counselors, teachers, police officers, and others. They have a broad range of decision-making powers related to orphans, from arranging medical check-ups to deciding which state a child will live in. They also schedule dental appointments, advocate for appropriate academic conditions, attend court hearings and teacher conferences, purchase clothing, assess adoptive parents, process adoption-related paperwork, and much more.

Yet, even with the significant responsibility as the substitute governance of orphan children, the "field of public administration has yet to undertake a systematic exploration of children within the contemporary literature" (Edlins, 2013). Unlike other fields that have adapted their thinking and action toward children, there is an absence of work in public administration's literature that considers children by contemplating their nature and needs in order to inform the interactions between public administrators and children. Even the literature that helps us understand the interactions between street-level bureaucrats and citizens, such as the works of Lipsky (1980) and Maynard-Moody \& Musheno (2003), lack a focus on children. This literature indeed focuses on interactions with adults, yet when children are mentioned, they are merely secondary characters or as categories of problems, such as misbehaving students. This oversight 
means there is a gap in our understanding about the interactions between public administrators and children; it also means there is a deficiency of guidance for these interactions.

However, although not focused on children, public administration's literature provides a wealth of information regarding how street-level bureaucrats make decisions and perform their work. These workers are known to function in tense environments characterized by high service demands, inadequate resources, and ambiguous expectations (Lipsky 1980). As a result of the nature of their work and the environment they work in, street-level bureaucrats rely on their own judgment (Hummel 1991; Tummers and Bekkers 2012; 2014), discretion (Lipsky 1980; Maynard-Moody and Musheno 2003; Meyers and Vorsanger 2007), and often must resort to a "flying by the seat of your pants" approach (Hummel 1991, 32). This use of personal discretion is inescapable because "street level bureaucracies require people to make decisions about other people" (Hudson 1989, 52) as they process individuals into appropriate categories to enable bureaucratic oversight of people as administrative units (Prottas 1979). In practice, the necessity to use personal discretion to work in a structured environment often means that street-level bureaucrats exert influence that is beyond their own authority such that they "can simply control clients" (Hudson 1989, 43).

At the same time that street-level bureaucrats rely on their own discretion to decide how to perform their work, they rely on their own judgment about the target populations they serve in order to make sense of the work that they do (Meyers and Vorsanger 2003). Their judgment about the people they work with is guided by their own beliefs and norms, as well as based on their personal biases. In the process of making sense of the work they do, the stories that streetlevel bureaucrats tell themselves, as well as the stories available to them through popular avenues become "sources of knowledge" for their public service (Hummel 1991; Meyers and 
Vorsanger 2003). In fact, all stories that are available to street-level bureaucrats invite them "to become engaged with the reality they represent" (Hummel 1991, 38); stories are therefore not merely entertainment, but also exist to inform the realities in which they work.

In the absence of public administration literature to guide or provide understanding around the interactions between orphans and the street-level bureaucrats that act as their parent, and because of the dependence of orphans on these public servants to make all important decisions in their day-to-day life, it is important to consider what influences might help streetlevel bureaucrats make sense of the work they do with these children. In other words, what stories exist that might influence how street-level bureaucrats think about orphans? What narratives might inform or merely influence the discretion and judgment they use in their work? Of course, it would be impossible to identify all of the stories that are available to street-level bureaucrats as "sources of knowledge." However, we can attempt to identify and consider the narratives that exist, with the knowledge that effective public administration requires balanced judgment and broad understanding (Denhardt and White 1986); the fact that it is children who are dependent on the governance of street-level bureaucrats makes this effort even more important.

\section{Superhero Stories, Romance Novels, and Horror Films}

In order to explore the stories that might influence the judgment and discretion of streetlevel bureaucrats who interact with orphan children, as well as to contribute to our broader understanding of these interactions, I look to popular narratives of fiction and other works of imagination as possible sources of narrative about orphans. By entering the public consciousness, also known as popular culture, works of fiction become "part of the cognitive base for making 
decisions about public policy and administration" such that they influence how public servants do their jobs (McCurdy 1995). In fact, the intersection of fiction (and other works of imagination) and public administration have long been considered; this can be seen as early as 1924 when Humbert Wolfe considered the representation of public servants presented in works of fiction (Wolfe 1932). In the literature that considers this intersection, the use of fiction is thought to be beneficial for public administrators (Egger 1944; 1959; Waldo 1968; Kroll 1965; 1981) and is thought to influence how public servants do their work (McCurdy 1995). Additionally, there is a tradition of using fiction as a teaching device in public administration courses to "illustrate principles and expand experience" (1995, 499; Hatcher 2006; Marini 1992; 1992b).

There is no shortage of narratives about orphans in fiction and other works of imagination. Stories from Jane Eyre (Bronte 1950) to Harry Potter (Rowling 2007) and many more, ${ }^{1}$ offer narratives about orphans, each with different presentations about who they are and how they function in society. In each orphan narrative, the individual messages communicated to audiences contribute to common archetypes of orphans. These archetypes become common images that affect our deepest convictions in such a way that "we are not even aware of their power in our conscious lives" (Iaccino 1994, 4). As common images, theses archetypes define and limit the ways in which individuals approach and respond to orphans (Slotkin 2000). In this way, each fictional orphan and the genres that contain their narratives contribute to or create myths about the real lives of orphans.

In this paper, I explore the orphan archetypes created in three areas of narrative, including superhero stories, romance novels, and horror films, and consider how these myths might impact the interactions between orphans and public administrators. The selection of these genres over 
others was a mere fact of convenience: in my early searches for works of fiction about children separated from their parents, these children were commonly referred to as "orphans" and were frequently available in superhero stories, romance novels, and horror films. In addition to the availability of relevant narratives within these genres, I believe these are good cases to explore for three reasons. First, these narrative genres are popular and widely available. Superheroes have been widely popular since the 1930's when they became available through single-hero comic books (Goulart 1990). In addition to the comic book medium, superheroes have gained popularity through movies, television shows, and an obvious presence in American culture (Reynolds 1994) and are now more popular than ever (Coogan 2006). Stories about romantic love are some of the oldest and most common stories. Romance is embedded in many of the fairytales told to children at young ages but remain popular to adults through novels, movies, and tv shows. Horror narratives are also widely available through tv shows and film. They are continually popular because "societies are constantly having to address the things which threaten the maintenance of life and its defining practices" (Wells 2000, 10).

Next, the characters in these genres resonate with commonly-held emotions. In other words, they are relatable. As "the embodiment of the American myth of the lone, rugged individual who comes into society and cleans it up," superheroes take on what humans dream of doing but do not know how to do (Muir 1995, 3). Romantic fairytales similarly draw on our hopes and dreams, while stories within the horror genre capitalize on fears and anxieties. By definition, horror films aim to scare audiences by exploring natural fears that emerge in the contemporary world, while also identifying appropriate sources of fear. The use of orphans in these myth narratives is meant to make the characters relatable, in that we feel with or for them. 
Finally, these genres offer us an opportunity to explore the unknown and to experience our own hopes and fears. Superhero stories are embedded with tropes of strength, bravery, and efficacy, which express the human need to feel control over our lives, no matter how bad the conditions around us get (Kaw 2005). These stories give readers the opportunity to "overcome our limitations, to soar and to unlock superpowers hidden within us" (Meyerson 2010). The romance genre gives us the experience of an extreme case of revival: a character starts from the very worst case (orphanhood) to the very best case (perfectly matched, passionate relationship). Horror stories allows us, even force us, to face the possibility of "a particularly violent and uncanny disruption of our unremarkable, everyday experiences” (Worland 2007, 2).

Within these genres, I examined three narratives in the superhero genre and six narratives each in the genres of romance novels and horror films, all based on their availability. The titles are displayed in the following table. For superhero stories, I focused on the three best-known superheroes because they have the oldest and most established storylines, as well as the fact that there is a range of literature establishing the importance of their orphan status. For romance novels and horror films, the cases were selected based on the presence of a main orphan character. $^{2}$ 


\begin{tabular}{|l|l|l|l|l|}
\hline & & & Author/Director & $\begin{array}{l}\text { Main/orphan } \\
\text { character }\end{array}$ \\
\hline Superhero & & & Title & \\
\hline & 1 & Superman & DC Comics & Clark Kent \\
\hline & 2 & Batman & DC Comics & Bruce Wayne \\
\hline & 3 & Spiderman & Marvel Comics & Peter Parker \\
\hline Romance & & & & \\
\hline & 1 & A Kiss to Remember & Medeiros & Laura Fairleigh \\
\hline & 2 & Irish Thoroughbred & Roberts & Adelia Cunnane \\
\hline & 3 & Desperate Measures & Michaels & Pete Sorenson \\
\hline & 4 & Less of a Stranger & Roberts & Megan Miller \\
\hline & 5 & Shades of Twilight & Howard & Roanna Davenport \\
\hline & 6 & Heather and Velvet & Medeiros & Prudence \\
\hline Horror & & & & \\
\hline & 1 & Whisper & Hendler & David \\
\hline & 2 & Case 39 & Alvart & Lillith \\
\hline & 3 & Orphan & Collet-Serra & Esther \\
\hline & 4 & The Orphanage & Bayona & (ghost orphans) \\
\hline & 5 & House of Voices & Laugier & (ghost orphans) \\
\hline & 6 & Hurt & Stepansky & Sarah \\
\hline & & & & \\
\hline
\end{tabular}

The following section will trace the narratives of these genres to identify the archetypes of orphans that they create and demonstrate how the emergent myths about orphans provide a perspective through which street-level bureaucrats might approach some of the orphans they interact with.

\section{Superhero Stories}

Many, perhaps even most ${ }^{3}$, superheroes are orphans. However, most notably orphaned are the big three: Superman, Batman, and Spiderman. Superman's parents died when their planet, Krypton, exploded. In an effort to save him, they sent him hurtling toward Earth in a rocket, where he was taken as an orphan and adopted. Before becoming Batman, young Bruce Wayne witnessed the brutal murder of his parents. Peter Parker, who would become Spiderman, 
also experienced the death of his parents early on and was taken in by his Uncle Ben ${ }^{4}$ and Aunt May (Goulart 1990).

For many superheroes, their orphan status is the driving force of their character (Daniels 1995; Fingeroth 2004; McWilliams 2009). As part of an evolving mythology, these characters are seen as loners, who because they are "cut loose from family responsibilities, [are] an inherent part of the romance of America, of the myth of eternal fresh starts" (Wirth-Nesher 1986, 260). At the core of these superheroes, are two primary elements that make them extraordinary: they succeed in the pursuit of a valiant mission, despite their great loss, and access great power and resources to do this. These attributes of resilience and access to resources lay the foundation for an emergent archetype of orphans as superheroes.

\section{Resilience}

Although they experience significant loss early on, Superman, Batman, and Spiderman are not harmed or held back by their loss, but are instead able to succeed by taking advantage of the "benefits" their orphan status bestows on them. They channel their grief and guilt into a mission to avenge their loss. Both Superman and Batman are motivated to reconcile their loss of family and sense of home. Superman was separated not only from his parents, but also from his home planet of Krypton. To reconcile that loss, he attempts to restore social justice to Earth and make it more like Krypton (Coogan 2006). In addition to this separation, Superman is left with feelings of guilt because he survived while his parents perished on Krypton (2006). Thus, "he constantly lives in such a way as to set himself apart from society because he feels inadequate" (McWilliams 2009, 14). Compared with Superman's altruistic drive, Batman's motivation has roots in anger. Scarred by witnessing the gruesome murder of his parents, Bruce Wayne created 
an alter ego in order to seek revenge on criminals across his city. For Spiderman, motivation emerges from his own failure. Shortly after receiving his spider-powers, Peter Parker's Uncle Ben was killed by a thief. Because he was not there to prevent the crime and failed to catch the murderer for his original theft, Spiderman blames himself (Fingeroth 2004; Goulart 1990). Altogether, these three orphans rise above their experiences by channeling their loss into individual missions.

The loss of their parents generates a unique freedom for Superman, Batman, and Spiderman to pursue their own agendas (Coogan 2006). Although each character had other people who cared for them, they do not have to answer to parents or make time for them in traditional ways; they have a freedom from family obligations that allows them to pursue their main purpose (Fingeroth 2004; Wirth-Nesher 1986). This lack of attachment and oversight is not seen as a detriment to the characters, rather it is portrayed as a benefit as it frees them up to operate outside of the typical demands of family. To some extent, these orphans are presented as actually better off without their parents, because it allows them to become superheroes. This loss gives them the purpose to be a "champion of the oppressed" and to fight "evil and injustice" (Detective Comics, Inc. v. Bruns Publications 1939); the loss also provides them freedom to pursue their mission. In this way, the orphan status of a superhero becomes appealing; it is seen as an asset rather than a liability. ${ }^{5}$

\section{Access to Resources}

Along with the ability to channel their loss into something great, these superheroes are blessed with resources that are unparalleled by others and the ability to make use of these resources to pursue their mission (Coogan 2006). Superman, as the first true superhero, emerged 
with enough resources to make him very unique but also was given additional powers over time which allowed him to fly (instead of merely super-fast running), fend off any type of danger (atomic bomb included), push planets, throw buildings, and use x-ray vision to see through anything (Daniels 1995). ${ }^{6}$ Unlike Superman, Batman had no supernatural powers but instead had access to financial resources that enabled him to devote "years to preparing for his crime-fighting career, turning himself into both a master scientist and a top athlete" (Goulart 1990, 23). These abilities, paired with the best devices money could buy, give Batman his superhero power. Similar to Batman, Peter Parker began with no supernatural powers; he was just an average teenager until a radioactive spider bit him, giving him "strength, agility, wall-crawling ability, and an intuition for danger" $(1990,347)$.

In addition to their physical and supernatural resources, superheroes are marked by unlimited possibilities. Although they endured the nightmarish experience of losing their parents, these characters are not destitute of options or choices. This is evident in the resources available to them and the power they have to choose between resources. For Batman, these resources are financial. As a millionaire, he has the "opportunity to outfit himself with all the high-tech tools that an underfunded, overstressed metro police force could not afford" (Muir 1995, 71). His utility belt contains "an endless supply of lifesaving gadgets" (Goulart 1990, 23). In addition to the belt, he has the Batmobile, Batboat, Batsub, Batgyro (helicopter), and Batplane. To house these tools of revenge, Bruce Wayne was able to expand the Batcave until it became "a bottomless pit with room for a garage, a hangar, a laboratory, a trophy room and even a gymnasium" (Daniels 1995, 79).

Although not blessed with immense financial resources like Batman, Superman is privileged with increasing choices. He debuts as a hero, super in rank, with the ability to squash 
the common criminal. However over time, his powers increase dramatically_instead of merely overruling criminals, he can extinguish atomic bombs; rather than running across states with a super-human speed, he develops the power of flying. As these alternatives emerge for him, Superman is able to choose his causes and to alter his mission to fit his preference. At his beginning, Superman is a do-gooder, working as "a savior of the helpless and the oppressed" (Goulart 1990, 351). He helps widows and orphans; he stops abuse to the vulnerable; he holds back drunk drivers and gamblers. With a concentration on domestic violence and government corruption, he relies on his social conscience to addresses the issues important to him. The ability to choose between good options as well as the resources and powers available to these superheroes ensure their success in each situation.

In each of their stories, access to resources-whether supernatural powers, wealth, possibilities, or choices - elevate these superheroes above crooks and villains. But it is not just the resources they have access to, it is also their ability to harness these resources in ways that allow them to "effortlessly solve problems that the ordinary authorities cannot handle" (Coogan 2006, 231), without causing any danger to themselves. As such, they project an effortless efficacy demonstrated by their ability to do anything they set out to do.

\section{The Superhero-Orphan Myth at the Street-Level}

These narratives of superhero-orphans present an archetype of orphans as resilient and able to take advantage of the many resources available to them. In each story, the characters are able to translate the loss of their parents into a mission that not only defines them but also helps others. They have the freedom to do as they please and the resources to enable them. All together, these narratives present a character who does not suffer emotional struggles but is 
logical and determined. The superhero-orphan has access to resources that they are able to use to bounce back, and even succeed, in spite of their loss.

Under the influence of the myth that orphans are superheroes who will use their resources to succeed in spite of loss, a street-level bureaucrat may view an individual orphan as not needing a great deal from them. In this view, as long as they provide basic resources for the child, it is reasonable to expect them to be able to channel those resources in order to not only get by, but to succeed. For instance, a child in foster care may need an adequate placement and support services, but as long as those things are in place, it follows that the orphan should be able to successfully navigate their experience and succeed. This would be the same case with an orphan in juvenile detention or in-patient drug rehabilitation. Additionally, as long as those resources are available, even if it means multiple changes in a child's home or school placement, this myth holds that the child is resilient and supported with resources enough to bounce back. As an extension of this perspective, a street-level bureaucrat may not seek additional support and may have less patience with a child's on-going emotional struggles. If then a child does not embody this myth, the street-level bureaucrat may think, "It's nobody's fault but your own" because the orphan did not make logical decisions to succeed in spite of their situation.

\section{Romance Novels}

In romance novels, the "main plot centers around two individuals falling in love and struggling to make the relationship work" (Romance Writers of America 2011). Most wellknown romance writers have at least one storyline that revolves around an orphan, although many authors have multiple such storylines. ${ }^{7}$ In these stories, the Love-er is the active character, initiating and pursuing the Love-ee, who plays a more passive role in the process of falling in 
love and developing a relationship. ${ }^{8}$ Unlike the superhero genre, which displays the orphan as the ultimate hero, orphans in romance novels are most often the Love-ee, or passive character. Although usually the novel's protagonist, this character is in a position to merely respond to the advances and efforts of the Love-er; they are often at the mercy of the Love-er in order to maintain their livelihood, status, or security. The ways in which orphan characters are depicted in tales of romance generate the sleeping-beauty-orphan archetype, which portrays orphans as primarily motivated by a need to be saved by a romantic love in order to enjoy a happy ending.

\section{Need to be Saved}

Unlike superheroes who can channel their experience of loss into a mission, orphans in the romance genre are often portrayed as unable to recognize, process, or act on their feelings. As a result, orphan characters are unaware of the good things that happen in their lives; they are often made aware of their own feelings and what is best for them by other characters. This deficiency places them in debt of their Love-er and creates a situation where they need to be saved from their own foolishness. In Desperate Measures (Michaels, 2010), everyone but Pete, who spent his childhood shuttling from foster home to foster home, knows that he is in love with Annie. Annie, of course, loves him and is patiently waiting for Pete to recognize what everyone else already knows. When the realization of his love for Annie catches up with Pete, he admits, “I guess I always loved you. I was just too stupid to know it" (Michaels 2010, 380). Less of a Stranger's (Roberts 2003) Megan cannot believe that Davis could truly love her and convinces herself that he is out to get the family business. She is sure that what she truly wants is "for him to go away and leave us alone" (Roberts 2003, 102) but after it occurs to everyone else, Megan realizes that, while Katch was interested in the family business, his primary interest was in her. 
Similarly, in Irish Thoroughbred (Roberts 2007), Adelia cannot believe that Travis could truly love her and therefore must continuously be convinced by Travis that he loves her and wants to be married to her.

In these stories, orphans are characterized as lacking autonomy, even in situations with the people who love them. In Shades of Twilight (Howard 1997), Roanna is desperately in love with Webb, but when he leaves, she effectively stops living. She is powerless to stop him from leaving; she is powerless to keep herself alive once he is gone. Even ten years later, she has not been able to resurrect her life in his absence. She floats through life with a "blank doll face" which registers no passion, feeling, or personality. Even when Webb finally does return, Roanna remains powerless around him, explaining, "It's never been a secret how I feel about you. All you had to do at any time was snap your fingers and I'd have come running and let you do anything you wanted to me" $(1997,163)$. Similar to Roanna's compliant personality, Heather and Velvet's (Medeiros 2011) Prudence lacks authority in her own life and allows Sebastian to take advantage of her. Without ever voicing her feelings or the proposal she is considering, she allows herself to be kidnapped and then forcibly married to Sebastian.

\section{Happy Endings}

A crucial element of this archetype is the happy ending that all the characters find when they are rescued by their lover. Although the orphaned characters in romance novels are shown to have deficits that limit their own autonomy, they are always saved by a romantic character who secures a happy ending for them. In A Kiss to Remember (Medeiros 2002), Nicholas falls deeply in love with Laura; they marry and she is able to secure the house she is able to live on in her family home. In Irish Thoroughbred (Roberts 2007), Travis convinces Adelia of his love and 
they live happily ever after. In Heather and Velvet (Medeiros 2011), Sebastian recognized Prudence's hidden beauty and allows her to personality bloom. In Desperate Measures (Michaels 2010), Annie happily receives Pete's love. In Less of a Stranger (Roberts 2003), Megan is convinced by Katch that he is interested in her and they quickly marry. In Shades of Twilight (Howard 1997), Webb is able to melt Roanna's icy exterior and he builds her selfconfidence. Together they are able to solve the mysterious situations around them and live happily together.

In each case, the orphan is not able to create good out of their bad situations; they also struggle to accept good from others. A happy ending is only possible because the lover sweeps into save them from their dependence and helplessness.

The Sleeping-Beauty-Orphan Myth at the Street-Level

In each of these tales of romance, the helpless orphans are moved through the story as pawns, completely powerless to their own development or outcomes. They need to be saved because of an emotional debt that comes from their lack of awareness, not only of how their Love-er feels, but also of their own feelings. This indebtedness is made possible by the orphan status, which seemingly defines the character as unable to recognize their emotions, accept their attractiveness, and receive the love of another person. The situations in each of these stories reveal a power differential between the Love-er and Love-ee that establish the Love-ee's dependence on the Love-er for their security, a manifestation of their lack of autonomy.

Under this myth of needing to be saved in order to find a happy ending, the street-level bureaucrat becomes all-important. The work becomes all about the bureaucrat, who works to meet their own personal needs of altruism and co-dependence. By amplifying the importance of 
the public administrator, this myth in turn infantilizes the orphan and robs them of their selfdetermination and autonomy. The street-level bureaucrat is likely to make decisions for the child without consulting them, often without informing them, as the one who "knows best." These decisions might include choosing a permanent placement for the child, based on the criterion of what is most likely to "save" the child. It might also include limiting the orphan's opportunities or risks, based on the idea that the orphan is incapable of acting on their own. For the street-level bureaucrat, the likely result of this myth is burnout. If then a child does not embody this myth, or is not rescued for a happy ending, the street-level bureaucrat they started will not be around. As a result of this myth, the orphan would be crippled by the infantilization and in a self-fulfilling turn of events, they would not know how to act for themselves.

\section{Horror}

Horror films typically employ a monster or devil who creates an unwanted, and often dangerous, disruption. This devil represents "a projection of particular threats, fears and contradictions that refuse coexistence with the prevailing paradigms and consensual orthodoxies of everyday life. The devil may also be perceived as a direct and unfettered expression of the horrors that surround us" (Wells 2000, 9). While horror films have often included orphans as characters, ${ }^{9}$ recent films have featured an orphaned child as the devil who is evil and beyond repair.

\section{Evil}

In the opening minutes of Whisper (2007), a black screen displays 2 Corinthians 11:14, "And no wonder, for Satan himself masquerades as an angel of light." The film's "angel of light" 
is David, who appears to be a sweet and normal 8 year old, but turns out to be an evil child, who is out for murder. After causing the brutal murders of five people, David makes it clear that he is "casting for souls" and killing anyone in his way.

In Case 39 (2011), Lilith convinces social worker Emily to take her in, yet quickly turns her evil on her. After Emily's closest friends die bizarre deaths, Emily begins to see that her "sweet and intuitive" foster daughter is also a callous and calculating psychopath. She seeks out Lilith's father who explains that Lilith intends "to know what your idea of hell is... and make you live there." Not able to comprehend such evil in a child, Emily asks what Lilith is and her father responds, "Whatever evil she is, didn't come from us. It was already there. From the moment she came into being, she brought something with her. Something older, destructive. Soul of a demon."

In Orphan (2009), Kate and John are initially drawn to Esther over the other orphans because she appears quiet and perceptive. However, it quickly becomes clear that Esther is no innocent victim as she deliberately harms those around her: she brutally kills Sister Abigail with a hammer, bashes in the head of a bird with a rock, pushes a little girl off a playground structure, and physically threatens both of her new siblings. Esther's villainy escalates as she almost kills her brother, succeeds in brutally murdering her father, and desperately attempts to kill her mother.

In other films, the evil orphan character is less obvious. In The Orphanage (2008), Laura's son Simon disappears and she suspects he has been taken away by the ghosts of past orphans who lived in the orphanage. As the story unfolds, Laura begs the orphanage to return her son, at times actually calling out to the house, as she begins to confirm details of the orphans who lived there in the past. In a similar story, when Anna arrives at the orphanage in House of 
Voices (2005), she begins to sense a supernatural presence and hears mysterious voices. This escalates as the orphanage itself seems to rise up as a character, making noises and slamming doors, in order to intimidate and communicate with her.

In each of these stories, orphans are portrayed as having supernatural evil that enables their evil. However in Hurt (2009), young Sarah Parsons' malevolence stems from witnessing the tragic death of her parents and an intense desire to get revenge on those she believes are responsible for her pain. Even without additional powers to spur her violence, Sarah's extreme grief provokes her to kill, or almost kill, all the people she encounters. Whether by extraordinary means or merely by the experience of tragedy, these orphans are manipulative, powerful, and ruthless.

\section{Irreparable}

In these stories, characters volunteer to help the orphans even though they are in vulnerable situations, only to discover that the orphan is beyond love and repair. The main parent-characters in both Orphan (2009) and Hurt (2009) are struggling with great loss, yet open their homes to an orphan out of the goodness of their hearts. While they struggle with their own pain, they are open to supporting and loving the orphan child. But, ignoring the hurt around them, as well as taking advantage of it, Esther and Sarah refuse to be helped by these supportive families. Instead they viciously prey on the very people who have offered to care for them, despite their less than ideal conditions. Resistant to support and love, these orphans demonstrate that they are beyond repair.

In many stories, it is only the death of the orphan at the hand of the parent-character that can end their destruction. Here, the orphans beg their new parent to save them and forgive them 
their evil. Esther calls out to Kate, "Don't let me die, Mommy!" (Orphan 2009). Lilith similarly begs Emily, "Please...don't let me die, Mommy" (Case 39 2011). Making an emotional plea, the orphans request that their new parent love them as they might their own child and give them a second chance, forgiving their evil behavior. In other situations where orphans face defeat by those who set out to help them, they taunt the opposing character. Sarah highlights her own corruption as a result of her trauma by challenging her sister, "You can't hurt me, you don't know how" (Hurt 2009). David also highlights this by telling Max, "You couldn't kill me, you don't have it in you" (Whisper 2007). These characters have reached the height of evil, such that they cannot recover but must die for things to get better.

\section{The Devil-Orphan Myth at the Street-Level}

The narratives of these horror films present an archetype of orphans as evil and beyond repair. They enter seemingly sweet and vulnerable, in need of people who will love and support them in their time of need. But instead of accepting this effort, these orphans morph into monsters who endeavor to kill those around them. This creates a myth that orphans, specifically certain orphans, are a "lost cause", in that they are evil and irreparable. These orphans, rather than to create concern about themselves, actually create concern for those around them because they are likely to ruin things and people around them.

Influenced by this myth of evil and irreparable orphans, a street-level bureaucrat would approach interactions with individual orphans with diminished commitment and diligence. Rather than explore feelings or causes of behavior, they would be eager to silence it. For instance, to allow prescribed psychotropic medication or punitive treatment. This myth would make a street-level bureaucrat more amenable to institutionalization, rather than advocating for 
therapeutic or community support. Working with "lost causes", a street-level bureaucrat's involvement and actions become less important. They would be less likely to fight for unique or creative solutions for an orphan, under the assumption that nothing will work. They would put others ahead of the orphan, given the need to protect others from the danger and potential harm from the orphan. In most cases, these interactions would, in a self-fulfilling type of way, ensure negative outcomes for the orphan. If then a child does not embody this myth, the street-level bureaucrat may then think "I told you so" or "Glad I didn't make an investment in that kid!"

\section{Possible Implications of Orphan Myths}

The popular narratives in superhero stories, romance novels, and horror films frame myths about orphans: that they are resilient and resourceful; that they need to be saved in order to find a happy ending; and that they are evil and beyond repair. Each of these stories provides us examples of children who have been separated from their parents, along with an archetypal narrative about how these orphans fared in spite, or as a result of, their orphan status. All together, these orphan myths suggest a nature of inevitability about the outcome of an orphan: that they will bounce back from their struggles, that someone will rescue them for a happy ending or that they will ruin everything and everyone around them.

Although these are stories, mostly far-fetched stories, we know that narratives are subsumed into the public consciousness in ways that affect how public servants perform their jobs (McCurdy 1995; Slotkin 2000). We also know that these public servants become the direct administrators of the day-to-day lives of children who are separated from their parents, whether temporarily or permanently. Given the constraints of their jobs and work environments, in addition to the absence of public administration literature, what are the possible implications of 
these myths to the interactions between street-level bureaucrats and real-life children who are separated from their parents?

First let us consider the possibility that these myths about orphans, coupled with streetlevel bureaucrats' reliance on their own discretion and the lack of public administration literature, may influence these interactions in ways that are bad for children. As previously identified following the discussion of each myth, a negative implication may occur when a public servant uses their discretion in ways that reflect the individual archetypes that emerge from popular narratives. For instance, a case-worker who assumes an orphan will bounce back in challenging situations, may be willing to allow their orphan client to make multiple foster home moves. This reflection of any of the individual orphan myths could be harmful to orphans. However, the negative implications of these myths may be much broader in their influence on street-level bureaucrats and their interactions with children.

Together, the myths that emerge from these narratives suggest that certain outcomes are inevitable for orphans: success, rescue, or failure. But at the core of this is an assumption of who or what is responsible for the future outcomes of orphan children. The myth that orphans will access the resources available to them in order to succeed suggests that an orphan is fully responsible for their response to their orphan experience, as well as for the eventual direction of their life. However, the myth that an orphan will only find a happy ending through someone else puts all the responsibility for a positive outcome on someone from the outside swooping in for a rescue and devalues the orphan's autonomy in their own life. Likewise, the myth of evil and irreparable orphans suggests that nothing can be done to impact the orphan's outcome; they are doomed from the start. In the first case, all the self-determination and responsibility falls on the 
orphan, while in the latter two, the orphan has no autonomy to impact the outcome of their own life.

The inevitability of outcomes as proposed in these myths also allows for the assignment of blame in the event a child's eventual outcomes are not ideal. The superhero-orphan myth tells us that a child who does not bounce back to succeed is at fault: they should have taken advantage of the resources that were provided to them in order to overcome their loss and circumstances. The myth that orphans need to be saved by someone else in order to be happy sets the orphan's only hope on the possibility of finding someone who will rescue them with a fairytale ending. However, the blame still falls on them if this does not happen. The myth of orphans as evil and beyond repair suggests that there is no possibility of a good outcome; this child is lost before anyone can help.

By suggesting simplified outcomes from complex situations, these myths may become "work-processing devices" that allow street-level bureaucrats to categorize orphans and make decisions about how to work, given their significant workloads (Lipsky, 1980). Such a tool allows a street-level bureaucrat to simplify complicated situations into categories that allow them to efficiently do their jobs. This of course is not necessarily done consciously, but is part of a subconscious process of operating under the demands of a heavy workload. While perhaps more efficient, this type of processing does not necessarily translate to increased effectiveness when working with young humans who have unique emotions and feelings. In fact, the use of these myths as tool to prioritize their work with orphans may make street-level bureaucrats less effective, as simplifying techniques prevent individualized care. Thus these myths threaten to desensitize street-level bureaucrats to the needs and vulnerabilities of orphans.. 
However, not all the possible implications have to be negative; perhaps the implications of these myths on interactions could in fact be positive. Given the significant amount of discretion they have, as well as the closeness of their work to their clients' lives, street-level bureaucrats might use their discretion to the benefit of children who are separated from their parents. For instance, these myths might convince them that their orphan clients are even more worthy of their help, creating a type of "positive discrimination" (Goodsell 1981; MaynardMoody and Musheno 2003) such that they work harder, are more creative with solutions, or use their discretion to take liberal action for the child. Whether motivated by pity (orphans need to be saved) or genuine concern for the child's loss or separation, the amplified conditions of the orphan status through these narratives might generate positive implications for orphan children.

Lastly, it is also important to consider the possibility that these myths may have no real impact on the interactions between orphans and public servants. Individuals may be unaware of the narratives about orphans: they may not consume superhero stories, romance novels, or horror films; they may consume these narratives yet not make a connection between the stories and real-life children. Or perhaps they may know these narratives and recognize the archetypes of orphans presented, but choose to disregard them as possible influences on their work.

\section{Conclusion}

The possibility of these negative implications is concerning for two reasons. First, children are a vulnerable population. They do not have the agency to govern themselves, but depend on others to govern them. Second, children who are separated from their parents temporarily or permanently come under the direct governance of the street-level bureaucrats who both implement public policy and make their own policy through their use of discretion (Lipsky 
1980). These public servants essentially act as orphan children's parents, making and overseeing decisions that range from the day-to-day, like doctor's appointments and clothing, to the big and important, like where they will live, what medications they take, and how they progress in school. In this way, orphans are vulnerable as children, but doubly vulnerable as children governed by street-level bureaucrats, who receive little guidance for their interactions with these children. The danger of negative interactions between street-level bureaucrats and children is particularly concerning but also likely because they are clients without rights (Meyers and Vorsanger 2007).

There is currently a gap in understanding around the interactions between street-level bureaucrats and the children who depend on them because they are temporarily or permanently separated from their parents. Thus, these myths and their potential implications highlight a need for further research on these interactions and how street-level bureaucrats approach children as clients. Additionally, further research is necessary on the ways street-level bureaucrats use personal discretion in their interactions with children. This type of research will allow us to inform and understand the interactions that these public servants have with children who are separated from their parents. 


\section{References}

Baum, L. Frank. The Wonderful Wizard of Oz. Chicago: George M. Hill Company, 1900.

Brontë, Charlotte. Jane Eyre. New York: Modern Library, 1950.

Brontë, Emily. Wuthering Heights. New York: Harper \& Brothers, 1848.

Case 39. Directed by Christian Alvart. 2009. Los Angelos, CA: Paramount Home Entertainment, 2010. DVD.

Coogan, Peter. Superhero: The Secret Origin of a Genre. Austin, TX: MonkeyBrain Books, 2006.

Daniels, Les. DC Comics: Sixty Years of the World's Favorite Comic Book Heroes. New York: Bulfinch Press, 1995.

Denhardt, Robert B. and Jay D. White. "Integrating Theory and Practice in Public Administration." In Bureaucratic and Governmental Reform, edited by Donal J. Calista. Greenwich, CT: JAI Press, 1986. 311-320; citation from 316.

Detective Comics, Inc. v. Bruns Publications. 28 F. Supp. 399. (District Court, SD New York, 1939).

Dickens, Charles. Great Expectations. New York: James G. Gregory, 1861.

Edlins, Mariglynn. "Administration Without Consideration." Administrative Theory \& Praxis 35, no. 4 (2013): 529-552.

Egger, Rowland. "Fable for Wise Men." Public Administration Review 4, no. 4 (1944): 371-376. doi: $10.2307 / 972902$

—. "The Administrative Novel." The American Political Science Review 53, no. 2 (1959): 448-455.

Fingeroth, Danny. Superman on the Couch: What Superheroes Really Tell Us About Ourselves and Our Society. New York: Continuum International Publishing Group, 2004.

Goodsell, Charles T. "Looking once again at human service bureaucracy." The Journal of Politics 43, no. 3 (1981): 763-778. 
Goulart, Ron. The Encyclopedia of American Comics. New York: Facts on File, 1990.

Hatcher, William. "Introduction: Fiction and Leadership." Public Integrity 8, no. 3 (2006): 201206.

House of Voices. Directed by Pascal Laugier. 2004. Universal City, CA: Universal Studios, 2005. DVD.

Howard, Linda. Shades of Twilight. New York: Pocket Books, 1997.

Hudson, Bob. "Michael Lipsky and Street-Level Bureaucracy: A Neglected Perspective." In Disability and Dependency, edited by Len Barton, 41-52. Florence, KY: Routledge, 1989.

Hummel, Ralph P. "Stories Managers Tell: Why They Are as Valid as Science." Public Administration Review 51, no. 1 (1991): 31-41. doi: 10.2307/976634

Hurt. Barbara Stepansky. 2009. Thousand Oaks, CA: Monterey Media, 2009. DVD.

Kaw, Nigel. "The Comic Book Superhero: Myth For Our Times.” Refractory: A Journal of Entertainment Media 8 (2005). http://blogs.arts.unimelb.edu.au/refractory/2005/10/14/thecomicbook-superhero-myth-for-our-times-nigel-kaw/\#_ednref6.

Kroll, Morton. "Administrative Fiction and Credibility." Public Administration Review 25, no. 1 (1965): 80-84. doi: 10.2307/974010

. "The Third Dimension: The Uses of Fiction in Public Affairs." Dialogue 3, no.4 (1981): 9-12. http://www.jstor.org/stable/25610348.

Lipsky, Michael. Street-Level Bureaucracy: Dilemmas of the Individual in Public Services. New York: Russell Sage Foundation, 1980.

Marini, Frank. Literature and Public Administration Ethics. The American Review of Public Administration 22 no. 2 (1992): 111-125.

—. "The Uses of Literature in the Exploration of Public Administration Ethics: The Example of Antigone." Public Administration Review 52, no. 5 (1992): 420-426.

Maynard-Moody, Steven Williams and Michael Craig Musheno. Cops, Teachers, Counselors: Stories from the Front Lines of Public Service. Ann Arbor, MI: University of Michigan Press, 2003.

McCurdy, Howard. 1995. Fiction and Imagination: How They Affect Public Administration. Public Administration Review, Vol. 55, No. 6 (Nov. - Dec., 1995), pp. 499506. doi: $10.2307 / 3110340$. 
McWilliams, Ora C. ““'Hey Batman, What Are Your Parents Getting You for Christmas?”: The Orphan Narrative and Non-Traditional Families in American Superhero Publications." Electronic thesis. Bowling Green State University, 2009.

http://rave.ohiolink.edu/etdc/view?acc_num=bgsu1245711175.

Medeiros, Teresa. Heather and Velvet. Reprint. Fanfare, 2011.

. A Kiss to Remember. New York: Bantam Books, 2002.

Meyers, Marcia K. and Susan Vorsanger. "Street-Level Bureaucrats and the Implementation of Public Policy." In Handbook of Public Administration, edited by B. Guy Peters and Jon Pierre, 245-256. Thousand Oaks, CA: Sage Publications, 2007.

Meyersohn, Jon. "Superheroes: Jesus, Hercules, Superman, Iron Man, Inspire Fantasy.” ABC News, May 31, 2010. http://abcnews.go.com/2020/superheroes-jesus-hercules-supermaniron-man-inspire-fantasy/story?id=10770296.

Michaels, Fern. Desperate Measures. Reprint. New York: Ballantine Books, 2010.

Muir, John Kenneth. The Encyclopedia Of Superheroes On Film And Television. 2nd ed. Jefferson, NC: McFarland \& Company, 1995.

Orphan. Directed by Jaume Collet-Serra. 2009. Burbank, CA: Warner Home Video, 2009. DVD.

Prottas, Jeffrey Manditch. People Processing: The Street-Level Bureaucrat in Public Service Bureaucracies. Lexington, MA: Lexington Books, 1979.

Reynolds, Richard. Super Heroes: A Modern Mythology. Jackson, MS: University Press of Mississippi, 1994.

Roberts, Nora. Less Of A Stranger. Ontario, Canada: Silhouette, 2003.

—. Irish Thoroughbred. Reprint. Ontario, Canada: Silhouette, 2007.

Romance Writers of America. "The Romance Genre Overview." http://www.rwa.org/cs/the_romance_genre. (accessed May 9, 2011).

Rowling, J. K. and Mary GrandPré. Harry Potter and the Deathly Hallows. New York: Arthur A. Levine Books, 2007.

The Orphanage. Directed by Juan Antonio Bayona. 2007. Burbank, CA: New Line Home Video, 2008. DVD. 
Tummers, Lars, and Victor Bekkers. "Policy Implementation, Street-level Bureaucracy, and the Importance of Discretion." Public Management Review 16, no. 4 (2014): 527-547.

Twain, Mark. The Adventures of Tom Sawyer. Hartford, CT: American Publishing Company, 1881.

Waldo, Dwight. The Novelist on Organization and Administration: An Inquiry Into the Relationship Between Two Worlds. Berkeley, CA: Institute of Governmental Studies, University of California, 1968.

Waldo, Dwight. The Administrative State: A Study of the Political Theory of American Public Administration. New Brunswick, NJ: Transaction Publishers, 2006.

Wells, Paul. The Horror Genre: From Beelzebub to Blair Witch. London: Wallflower Press, 2000.

Whisper. Directed by Stewart Hendler. 2007. Los Angelos, CA: Universal Studios Home Entertainment, 2009. DVD.

Wirth-Nesher, Hana. "The Literary Orphan as National Hero: Huck and Pip." Dickens Studies Annual 15 (1986): 259-273.

Wolfe, Humbert. "Some Public Servants in Fiction." Public Administration 2, no. 1 (1924): 3957.

Worland, Rick. The Horror Film: An Introduction. Hoboken, NJ: Wiley-Blackwell, 2007. 


\section{Endnotes}

${ }^{1}$ Consider: Dorothy Consider in The Wonderful Wizard of Oz (Baum 1900), Tom in The Adventures of Tom Sawyer (Twain 1881), Pip in Great Expectations (Dickens 1861), Heathcliff in Wuthering Heights (Brontë 1848), and the list could go on. More recent than these classic novels, popular movies tell stories about orphans, including James Bond, Harry Potter, Aladdin, and Good Will Hunting. Even popular television shows including storylines related to orphans: Modern Family, Brothers \& Sisters, Private Practice, Bones, House, and multiple soap opera series.

${ }^{2}$ It is important to note that the discussion of these genres, as well as the specific titles within them, is not meant to be exhaustive. Rather this is my attempt to identify some of the available narratives about orphan children, and the archetypes that emerge about who these children are, as well as to consider the possible implications of these narratives for the interactions between public servants and children separated from their parents.

${ }^{3}$ Beyond these three, many other superheroes are orphans: Aquagirl, Aurora, Captain Marvel, Daredevil, Green Lantern, Gypsy, and Roy Harper. Additionally, many of the X-Men cast are orphans, including Bishop, Cyclops, Havok, and Jubilee.

${ }^{4}$ Early in Spiderman's storyline, his uncle is also murdered, subjecting him to a second orphaning.

${ }^{5}$ As it glorifies the freedom associated with the orphan status of superheroes, this myth-narrative provides an escape reality for non-orphans wanting to escape their families (Coogan 2006).

${ }^{6}$ In 1963, Lois Lane confirmed that Superman also had acquired the power of the "superkiss" (Daniels, 1995).

${ }^{7}$ Consider: Nora Roberts, Linda Howard, Jude Deveraux, Judith McNaught, Susan Elizabeth Phillips, Julie Garwood, Kristin Hannah, and many more.

${ }^{8}$ These characters are generally referred to as the hero and the heroine. However, as this suggests, the heroine is not always a female character, nor the hero a male character (by definition, a hero is a man, while a heroine is a woman). Instead, these terms refer to the role the characters play with in the evolution of their love and relationship. Because gender has historically been assigned to hero and heroine and they can thus become a complicating rather than clarifying terms, I will refer to these character roles as the Love-er and the Love-ee. Love-ers (or heroes) are the active character. These characters, whether man or woman, are the determined pursuer and initiator of love. They are clear in their affections and determined to win over their Love-ee. The Love-ees (or heroines) plays a more passive role in the process of falling in love and developing a relationship. They are typically the one to be swept off their feet; the one to wake up towards the end of the novel, suddenly surprised by their feelings.

${ }^{9}$ Orphans have long held major roles in horror films. Consider: Psycho (1960), The Innocents (1961), and The Shining (1980). The Omen (1976) is generally thought to be the first horror film that featured an orphan child as the devil, rather than a common character. 